\title{
KOMUNIKASI INTERPERSONAL KEPALA SEKOLAH DALAM MENINGKATKAN PRESTASI AKADEMIK DI SDN 10 SERINDANG
}

\author{
Ana Suha, Sukmawati, Usman Radiana \\ SDN 03 Tebas, Kabupaten Sambas \\ Email:f2171191027@student.untan.ac.id
}

\begin{abstract}
The form of this research is a qualitative approach. The subjects of this study were 1 principals and 11 teachers. Methods of collecting data through observation, interviews, documentation, and triangulation. While the data analysis used qualitative data analysis. While the validity of the data is tested in four ways, namely internal validity, transferability, dependability, and confirmability. The main findings in this study: (1) The principal has implemented interpersonal communication occurs directly between the principal and the teacher, close relationship in communication, teachers occur in a long time and the principals and teachers know each other's personal characteristics. (2) Barriers to interpersonal communication passed by the principal, namely time barriers, social media that does not support, physical influence between male teachers and female teachers, and the psychological influence of which is the age factor. (3) to overcome the principal's interpersonal communication barriers build a high empathy attitude towards the teacher's task, get used to being a good listener, repeat information that is not clear, then determine an effective time to communicate interpersonal. The conclusions in this study are the principal has implemented interpersonal communication in improving academic achievement at the school, Obstacles in the implementation of interpersonal communication that the Principal goes through consist of time constraints, media influences, physical influences, and psychological influences, the principal has overcome obstacles in interpersonal communication.
\end{abstract}

\section{Keywords: Academic Achievement, Interpersonal Communication}

\section{PENDAHULUAN}

Prestasi akademik sering juga disebut prestasi belajar. Rosyid dkk (2019, p.9) mengungkapkan bahwa prestasi belajar merupakan hasil dari suatu kegiatan pembelajaran yang disertai perubahan yang dicapai seseorang (siswa) yang dinyatakan dalam bentuk simbol, angka, huruf, maupun kalimat sebagai ukuran tingkat keberhasilan siswa dengan standarisasi yang telah ditetapkan dan menjadi kesempurnaan bagi siswa baik dalam berpikir dan berbuat.

Untuk mencapai prestasi akademik yang baik diperlukan kerjasama yang baik dari seluruh warga sekolah. Kompri (2014, p.155) mengatakan bahwa kerjasama dari warga sekolah yang efektif dapat dilakukan dengan banyak cara baik itu secara formal maupun non formal yang bertujuan untuk kemajuan sekolah. Kerjasama yang baik itu pula terbangun dari hubungan yang baik antara kepala sekolah, guru, siswa, dan orangtua siswa yang saling menghormati, menghargai, bekerjasama, komunikatif, disiplin dan penuh rasa tanggung jawab.

Komunikasi interpersonal merupakan cara yang efektif untuk memberi pemahaman secara lebih mendalam kepada guru akan pentingnya prestasi akademik merupakan hal yang sangat penting dari aktivitas belajar. Komunikasi jenis ini terjadi secara langsung dan mendalam antara kepala sekolah dengan guru yang bersangkutan. Oleh sebab itu komunikasi interpersonal 
merupakan cara yang paling dasar untuk memengaruhi perubahan prilaku seseorang.

Oleh sebab itu, diharapkan dengan penerapan komunikasi interpersonal ini bisa menjadi alternatif yang digunakan kepala sekolah untuk guru yang kurang mampu mengungkapkan masalah pribadinya dalam mendidik siswa secara terbuka di depan guru-guru yang lain. Penerapan komunikasi interpersonal oleh kepala sekolah juga diharapkan agar guru akan lebih leluasa menyampaikan seluruh persoalannya secara luas dan mendalam sehingga ruang diskusi untuk mencari solusi akan menjadi lebih mudah dengan demikian permasalahan akan terselesaikan dalam waktu yang relatif cepat. Hal tersebut tentunya akan berdampak pada prestasi akademik siswa.

Namun kenyataannya masih banyak kepala sekolah yang belum mampu menerapkan komunikasi interpersonal terhadap guru secara maksimal. Komunikasi antara kepala sekolah dengan guru hanya bersifat formal dan kedinasan. Hubungan kepala sekolah benar-benar seperti atasan dan bawahan, seperti bos dan karyawan sehingga tidak sedikit guru yang kesulitan menggungkapkan persoalan yang dihadapinya saat mengajar di kelas. akhirnya guru datang ke sekolah hanya sekedar melepaskan kewajiban sebagai pendidik.

Pada penelitian kali ini, peneliti mengambil tempat di Sekolah Dasar Negeri (SDN) 10 Serindang Kabupaten Sambas.

SDN 10 Serindang merupakan sekolah yang dikenal sekolah yang memiliki prestasi akademik yang baik. Hasil pengamatan awal dilapangan menunjukkan bahwa sekolah ini memiliki prestasi yang stabil dalam bidang akademik. Jika dilihat dari hasil Ujian Sekolah, berdasarkan pada Undang-undang Nomor 19 Tahun 2005 tentang Standar Nasional Pendidikan mengatakan bahwa ujian adalah proses yang dilakukan untuk mengukur pencapaian kompetensi peserta didik sebagai pengakuan prestasi belajar (akademik) dan/atau penyelesaian dari suatu satuan pendidikan. Sekolah ini selalu berada diperingkat enam besar dalam kurun waktu lima tahun terakhir di Kecamatan Tebas yang terdiri dari 51 Sekolah Dasar Negeri.

Berdasarkan wawancara awal, sekolah ini memiliki kebiasaan baik untuk mendukung peningkatan prestasi akademik siswa yaitu melalui pelajaran tambahan di luar jam belajar sekolah. Program ini didukung penuh oleh guru dengan keterlibatannya mengajar pada saat pelajaran tambahan tersebut. Kepala sekolah juga mampu menyampaikan program unggulan sekolah ini kepada orangtua siswa.

Pola komunikasi yang dibangun kepala sekolah dengan pendekatan interpersonal merupakan perantara bagi sekolah ini memiliki budaya belajar yang baik sehingga berdampak pada prestasi akademik yang tinggi dan stabil.

Berdasarkan latar belakang yang telah dipaparkan di atas, peneliti tertarik untuk mengadakan penelitian mendalam dengan sudut pandang komunikasi interpersonal kepala sekolahnya dalam meningkatkan prestasi akademik di sekolah tersebut.

\section{METODE PENELITIAN}

Pada penelitian ini pendekatan yang digunakan ialah pendekatan kualitatif karena dalam memahami dan mengungkap fakta dilapangan akan sesuai dengan kenyataan tanpa mengitervensi kondisi yang terjadi dalam kata lain meneliti pada kondisi yang alamiah. Jenis penelitian yang digunakan dalam penelitian ini ialah jenis penelitian studi kasus dengan tujuan mendalami kasus komunikasi interpersonal dalam meningkatkan prestasi akademik di SDN 10 Serindang. Serta pendalaman informasinya melalui wawancara, observasi, dokumentasi, dan trianggulasi.

Dalam penelitian kualitatif peneliti merupakan instrumen kunci sebagaimana diungkapkan Creswell (2019, p.248) bahwa "Researcher as key instrument" yang bermakna peneliti sebagai instrumen kunci. Oleh sebab itu, kehadiran peneliti dalam penelitian ini tidak dapat digantikan oleh orang lain. Baik itu dalam proses pengumpulan data yakni wawancara, observasi, dokumentasi, dan trianggulasi 
mengenai komunikasi interpersonal kepala sekolah dalam meningkatkan prestasi akademik di SDN 10 Serindang hingga akhir penelitian yaitu proses analisis data.

Penelitian ini dilaksanakan di SDN 10 Serindang Kecamatan Tebas.

Karakteristik partisipan dalam penelitian ini digambarkan pada tabel 3.1 sebagai berikut:

\section{Tabel 1. Karakteristik partisipan penelitian}

\begin{tabular}{|c|c|c|}
\hline No. & $\begin{array}{c}\text { Karakteristik } \\
\text { Partisipan }\end{array}$ & Keterangan \\
\hline 1. & $\begin{array}{l}\text { Jumlah } \\
\text { partisipan }\end{array}$ & 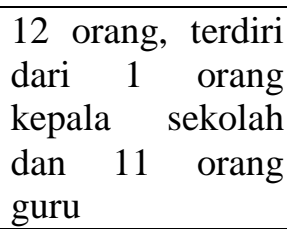 \\
\hline 2. & $\begin{array}{l}\text { Tipe } \\
\text { partisipan }\end{array}$ & $\begin{array}{l}\text { Terdiri dari } 6 \\
\text { orang guru PNS } \\
\text { dan } 6 \text { orang guru } \\
\text { honorer }\end{array}$ \\
\hline 3. & $\begin{array}{l}\text { Umur } \\
\text { partisipan }\end{array}$ & $\begin{array}{l}\text { usia guru } \\
\text { termuda ialah } 31 \\
\text { tahun, usia guru } \\
\text { paling tua ialah } \\
58 \text { tahun. }\end{array}$ \\
\hline 4. & $\begin{array}{l}\text { Jenis kelamin } \\
\text { partisipan }\end{array}$ & $\begin{array}{l}\text { Terdiri dari } 1 \\
\text { orang kepala } \\
\text { sekolah berjenis } \\
\text { kelamin laki-laki, } \\
3 \text { orang guru } \\
\text { laki-laki, dan } 7 \\
\text { orang guru } \\
\text { perempuan. }\end{array}$ \\
\hline
\end{tabular}

Pada penelitian ini, teknik pengumpulan data yang digunakan adalah observasi, wawancara, dokumentasi, serta trianggulasi kepada narasumber yaitu kepala sekolah dan guru tentang komunikasi interpersonal kepala sekolah dalam meningkatkan prestasi akademik di SDN 10 Serindang.

Pada penelitian kualitatif yang menjadi instrumen ialah peneliti itu sendiri (Sugiyono, 2019, p.293). Peneliti disebut sebagai instrumen penelitian dikarenakan ia merupakan perencana, pelaksana pengumpulan data, analisis, penafsir data, dan pelapor hasil penelitian (Meloeng, 2017, p.168). Sehingga yang melakukan validasi adalah peneliti sendiri melalui seberapa jauh pemahaman terhadap moetode kualitatif, penguasaan teori, dan wawasan terhadap bidang yang diteliti dan kesiapan bekal memasuki lapangan penelitian.

Peneliti akan menggali informasi berkaitan dengan komunikasi interpersonal dalam meningkatkan prestasi akademik di SDN 10 Serindang. Langkah awal peneliti akan menyiapkan kisi-kisi instrumen penelitian, pedoman observasi, pedoman wawancara, dan pedoman dokumen yang telah peneliti susun berdasarkan teori ahli dan dikonsultasikan kepada dosen pembimbing.

Pada penelitian ini teknik analisis data yang digunakan adalah analisis kualitatif. Analisis data kualitatif menurut Bogdan dan Biklen dalam Moleong (2017, p.248) ialah upaya yang dilakukan dengan cara bekerja menggunakan data, mengorganisasikannnya, serta memilahnya menjadi satuan yang dapat dikelola, kemudian mensitetiskannya dan dilanjutkan dengan mencari sekaligus menemukan pola dari apa yang penting dan apa yang dipelajari dan terakhir memutuskan apa saja yang bisa sampaikan kepada orang lain.

Teknik pengecekan data menurut Sugiyono (2019, p.364) terdiri dari 4 cara yaitu validitas internal, transferabilitas, dependabilitas, dan konfirmabilitas.

\section{HASIL PENELITIAN DAN PEMBAHASAN}

\section{Hasil}

Pengumpulan data dalam penelitian ini dilakukan dengan teknik wawancara, observasi, dan studi dokumen. Setelah dilakukan pengumpulan data dipaparkan sebagai berikut: Pola komunikasi yang dibangun oleh Kepala SDN 10 Serindang, berdasarkan hasil wawancara yang telah dilakukan, dimulai saat pelaksanaan rapat sekolah bersama guru di sekolah tersebut. Kepala sekolah memberikan ruang bagi guru untuk menyampaikan ide, saran, dan 
tanggapan terutama dalam hal upaya untuk mencapai prestasi akademik siswa yang terbaik sebagaimana telah dituangkan di dalam visi dan misi sekolah ini. Pada masa ini juga, guru diberikan keleluasaan untuk menyampaikan permasalahan yang dihadapi ketika melaksanakan tugasnya yakni mendidik dan mengajar.

Upaya yang dilakukan oleh sekolah ini, selain pembelajaran maksimal yang telah dilaksanakan oleh guru dalam proses mendidik dan mengajar pada jam sekolah, adalah pemberian pelajaran tambahan di luar jam efektif sekolah. Kepala sekolah menyampaikan bahwa program ini rutin dilakukan bahkan sudah menjadi kebiasaan baik sejak tahun 1995 bertepatan dengan penugasannya (kepala sekolah yang sekarang saat masih menjadi guru) di sekolah tersebut. Kebiasaan baik ini kemudian dilanjutkan dan diperkuat lagi saat ia diangkat menjadi kepala sekolah pada tahun 2011. Bentuk dari keseriusannya ialah dengan menganggarkan secara rutin biaya operasional bagi guru yang mengajar untuk kegiatan pelajaran tambahan sebagaimana dapat dilihat pada lampiran 17.

Kegiatan pelajaran tambahan ini diajar langsung oleh guru kelas masing-masing tingkatan. Semua siswa kelas I hingga VI diwajibkan untuk mengikuti kegiatan tersebut tanpa terkecuali. Secara khusus untuk siswa kelas VI yang akan menghadapi Ujian Sekolah akan mendapatkan pelajaran tambahan hingga jam 8 malam.

Komunikasi interpersonal Kepala SDN 10 Serindang berlangsung kontinyu, bukan hanya sekali-kali. Biasanya setelah melakukan rapat membahas sesuatu secara umum, Kepala SDN 10 Serindang akan memperkuat dengan melakukan komunikasi secara interpersonal pada setiap guru.

Tujuan sekolah untuk menjadi sekolah unggul yang dicintai masyarakat, berprestasi, berakhlakul karimah yang baik serta beriman dan bertaqwa terhadap tuhan yang Maha Esa sebagaimana tertuang dalam visi sekolah didukung oleh guru, orangtua, dan masyarakat sekitar tidak lepas dari pribadi kepala sekolah itu sendiri. Karakter kepala sekolah yang dikenal oleh guru sebagai orang yang bersemangat dalam bekerja, peduli, dan suka menolong ini menjadikannya dekat dengan guru di sekolah tersebut. Juga kepribadiannya yang ramah dan aktif dimasyarakat membuatnya diterima oleh masyarakat Serindang dengan mendukung program sekolah yakni mengizinkan anak-anak mereka mengikuti pelajaran tambahan tersebut.

Kepala sekolah dan rata-rata guru di sekolah tersebut adalah putra daerah Desa Serindang sekaligus alumnus SDN 10 Serindang. Hal ini secara tidak langsung memberikan rasa dekat secara pribadi bagi guru karena telah mengenal pribadi kepala sekolah dalam waktu yang lama dan membentuk hubungan kekeluargaan. Hubungan dekat ini tidak hanya terjadi di tempat kerja, namun juga berlangsung di lingkungan masyarakat. Kondisi ini, menurut guru, menimbulkan rasa nyaman dan mengurangi rasa canggung sehingga mereka lebih mudah untuk berkomunikasi baik itu menyampaikan ide, saran, kritikan bahkan keluhan terutama terkait program pelajaran tambahan.

Berdasarkan hasil wawancara dengan kepala sekolah. Di antara hambatan yang dialami diantaranya adalah pemilihan waktu untuk berkomunikasi secara interpersonal. Hal ini dikarenakan tugas guru yang padat yang biasanya hanya bertemu pada saat jam istirahat sekolah. Kemudian, berdasarkan jawaban guru di SDN 10 Serindang, kesibukan kepala sekolah di awal tahun pelajaran dan akhir tahun juga menjadi penghambat untuk menyampaikan permasalahan guru dalam melaksanakan tugasnya. Mereka mengatakan bahwa untuk menyampaikan sesuatu harus melihat situasi dan kondisi terlebih dahulu.

Hambatan komunikasi interpersonal lain yang dialami kepala sekolah dan guru SDN 10 Serindang ialah ketika melalui media sosial. Mereka memiliki jawaban yang serupa yakni apabila informasi yang harus disampaikan melalui media whats app atau telepon seringkali pesan itu direspon lambat oleh kedua belah pihak, baik itu pada kepala 
sekolahnya maupun dibagian gurunya. Hal ini biasa disebabkan oleh kualitas jaringan yang buruk serta posisi perangkat telpon yang tidak selalu berada di dekat pemilik telpon tersebut baik kepala sekolah maupun guru.

Fisik juga menjadi penghambat dalam berkomunikasi. Terutama bagi guru baru yang berbeda jenis kelamin. Guru perempuan, terutama guru yang lebih muda merasa segan dan malu menyampaikan permasalahannya. Hal ini berbeda dengan guru laki-laki yang lebih mudah dan santai untuk menyampaikan sesuatu. Hal ini dibenarkan ketika wawancara dengan kepala sekolah dan beberapa guru yang bersangkutan.

Selain hambatan-hambatan di atas, hambatan lainnya ialah hambatan psikologis. Selain beda perlakuan dalam berkomunikasi antara guru laki-laki dan guru perempuan. Usia juga menjadi faktor penghambat komunikasi. Perasaan tersinggung yang dirasakan oleh guru, maupun kondisi emosional yang sedang buruk membuat komunikasi interpersonal tidak berlangsung baik.

Diantara upaya yang telah dilakukan oleh kepala sekolah dalam mengatasi hambatan komunikasi interpersonal ialah dengan membangun rasa empati terhadap tugas guru. Sebagai bentuk empati, kepala sekolah berusaha memahami dan mensupport guru dalam melaksanakan tugasnya. Serta bersama-sama meningkatkan kompetensinya sebagai pendidik. Di antaranya dengan memenuhi kebutuhan laptop untuk masing-masing guru, menyediakan infocus untuk metode pengajaran baru, pemasangan wifi agar guru bisa menambah pengetahuan dan referensi mengajar dari internet. Serta menyediakan ruangan yang nyaman bagi guru.

Di antara kebiasaan yang dilakukan oleh Kepala SDN 10 Serindang ialah kebiasaan untuk mendengar. Kepala sekolah mendengarkan cerita-cerita guru dalam perjalanannya melaksanakan tugas pendidikan. Hal ini biasanya berlangsung pada saat jam istirahat, kepala sekolah yang juga berbaur disatu ruangan dengan posisi kursi duduk melingkar memudahkan untuk berkomunikasi satu dengan yang lain. Pada situasi tersebut, secara tidak langsung, guruguru menyampaikan permasalahannya dengan berbagi kepada kepala sekolah dan teman guru yang lain.

Diantara upaya yang dilakukan oleh Kepala SDN 10 Serindang untuk mengatasi hambatan yang terjadi saat berkomunikasi dengan guru jika ada informasi yang kurang dipahami ialah dengan cara kepala sekolah mengulangi informasi baik itu secara langsung pada saat kumpul jam istirahat maupun secara personal di ruangan kepala sekolah dengan menggunakan bahasa yang lebih sederhana.

Dalam melakukan komunikasi interpersonal kepada guru, Kepala SDN 10 Serindang selalu mempertimbangkan kesiapan psikologi dan kondisi kesehatan guru. Kesiapan yang dimaksudkan ialah kepala sekolah akan berkomunikasi dengan guru saat mereka tidak dalam keadaan sibuk atau sedang dalam kondisi santai dalam arti yang lain dilaksanakan pada waktu yang tepat.

\section{Pembahasan}

Paparan hasil penelitian di atas telah memberikan gambaran kepada peneliti untuk menyampaikan pandangan mengenai penerapan komunikasi interpersonal kepala sekolah dalam meningkatkan prestasi akademik di SDN 10 Serindang dengan batasan rumusan pertanyaan dan tujuan penelitian sebagaimana di ungkapkan pada bab pendahuluan.

Berdasarkan hasil temuan di atas diketahui bahwa Komunikasi interpersonal yang dilakukan Kepala SDN 10 Serindang terhadap guru yaitu dengan mengajak setiap guru secara individu untuk memberikan ide, saran dan masalah yang dialami saat mengajar di ruang kepala sekolah. Komunikasi ini hanya dilakukan dua orang yaitu antara kepala sekolah dan guru, kepala sekolah membangun kedekatan secara personal dengan guru, guru diberi kesempatan untuk menyampaikan apa saja 
hal-hal yang terkait dengan tugas mengajar di sekolah. Bila mana ada permasalahan, hal itu dipandang sebagai masalah bersama dan harus diselesaika betrsama bersama pula.

Komunikasi interpersonal yang dibangun kepala SDN 10 serindang menempatkan guru sebagai tim kerja, sahabat di sekolah yang bisa kapan saja diajak untuk bersama-sama menghadapi dan menyelesaikan permasalahan yang ada di sekolah. Sehingga guru sangat merasa dihargai dan diperlukan keberadaannya, Prestasi akademik yang diraih sekolah dirasakan oleh guru merupakan prestasi bersama.

Komunikasi interpesonal kepala SDN 10 Serindang berlangsung kontinyu, bukan sewaktu-waktu. Biasanya setelah melakukan rapat membahas sesuatu secara umum, kepala SDN 10 Serindang akan memperkuat dengan melakukan komunikasi interpersonal pada setiap guru.

Pola komunikasi interpersonal seperti ini dirasakan berdampak positif terhadap motivasi kerja guru, guru jadi lebih semangat dalam melaksanakan tugas-tugas di sekolah dan iklim di sekolah jadi lebih kondusif. Hal yang demikian membawa pengaruh meningkatnya prestasi akademik siswa SDN 10 Serindang.

Uraian diatas sejalan dengan pendapat Hartley (1993, p.20) mengatakan bahwa sesuatu itu disebut sebagai komunikasi interpersonal apabila: (1) komunikasi tersebut berlangsung antara satu individu ke individu lainnya, (2) komunikasi tersebut bersifat tatap muka, (3) bentuk dan isi komunikasi mencerminkan karakteristik pribadi individu tersebut serta mencerminkan peran dan hubungan sosial mereka.

Diantara usaha yang dilakukan sekolah ialah dengan membudayakan belajar tambahan di sore hari. Kebiasaan ini sudah dilakukan sejak lama yaitu tahun 1995 dan diperkuat ketika kepala sekolah saat ini menjabat yaitu tahun 2011. Seluruh siswa dari kelas I hingga kelas VI di wajibkan untuk mengikuti pelajaran tambahan ini yang dilaksanakan diluar jam pelajaran sekolah. Serta yang mengajar ialah guru dari kelas tersebut. Khusus untuk kelas enam pelajaran tambahan itu dilaksanakan hingga jam 8 malam.

Upaya yang dilakukan oleh sekolah untuk meningkatkan prestasi akademik dinilai telah efektif. Indikator efektivitas menurut Wibowo dalam dalam Wahyudi (2009, p.84) dapat dilihat dari kualitas program, ketepatan penyusunan, kepuasan, kemampuan adaptasi, semangat kerja, motivasi, ketercapaian tujuan, serta ketepatan pendayagunaan saran dan prasarana, juga sumber belajar dalam meningkatkan kualitas pendidikan di sekolah.

Tujuan sekolah untuk menjadi sekolah unggul yang dicintai masyarakat, berprestasi, berakhlakul karimah yang baik serta beriman dan bertaqwa terhadap tuhan yang Maha Esa sebagaimana tertuang dalam visi sekolah ini untuk di dukung oleh guru, orangtua, dan masyarakat sekitar. Untuk itu banyak faktor yang memengaruhi hasil belajar siswa tersebut untuk menjadikan sekolah ini unggul dan berprestasi. Hasil belajar siswa memberikan informasi kepada guru tentang kemajuan siswa dalam upaya mencapai tujuan belajar melalui kegiatan belajar (Rusman, 2017. p.130).

Untuk itu komunikasi diperlukan untuk menterjemahkan tujuan sekolah agar dipahami oleh semua masyarakat sekolah. Komunikasi yang digunakan kepala sekolah ialah komunikasi interpersonal yaitu komunikasi yang berlangsung antara dua orang yakni kepala sekolah dan guru, ada hubungan timbal balik diantara keduanya, ada proses transaksi interpersonal yakni hubungan dekat, serta terjadi dalam waktu yang lama dan berkelanjutan.

Dari hasil wawancara peneliti kepada partisipan menunjukkan bahwa kepala sekolah dalam melaksanakan komunikasi sering berlangsung antara dua orang yakni kepala sekolah dan guru (face to face). Kepala sekolah awalnya menyampaikan informasi secara umum kepada guru-guru diantaranya terkait kebijakan sekolah yang mengadakan pelajaran tambahan di sore hari 
di agenda rapat sekolah dan mensosialisasikannya kepada orangtua.

Kepala sekolah melibatkan seluruh guru dalam merencanakan program belajar tambahan. Pada tahap ini kepala sekolah meminta guru untuk memberi masukan sebagai evaluasi atas kekurangan di tahun sebelumnya. Sehingga tidak terulang kesalahan yang mungkin pernah terjadi atau mengambil poin unggul dari pengalaman tahun sebelumnya.

Adapun hal-hal yang dibahas pada tahap perencanaan program belajar tambahan antara lain:

1. Penyusunan jadwal pelajaran tambahan

2. Pembagian tugas untuk guru-guru yang dilibatkan

3. Penetapan waktu pelaksanaan pelajaran tambahan

4. Penentuan tempat atau ruang yang akan digunakan untuk belajar

5. Serta penetapan mata pelajaran yang akan di ajarkan

Hal ini sejalan dengan pendapat Thahir (2014, p.158 ) menjelaskan bimbingan belajar diberikan dengan tujuan untuk membantu siswa agar mudah mencapai tujuan pelajaran atau kemampuankemampuan yang harus dicapainya pada akhir pelajaran. Pembelajaran ini pula berupaya mengubah masukan siswa yang belum terdidik, menjadi siswa terdidik, siswa yang belum memiliki pengetahuan menjadi siswa yang berpengetahuan (Aunurrahaman, 2019, p.33).

Pada saat merencanakan program belajar tambahan, kepala sekolah benar-benar mempertimbangkan kondisi guru yang terlibat, baik itu kondisi jarak tempat tinggal guru, kondisi kesehatan, kesibukan guru dan sebagainya. Hal ini dimaksudkan untuk meminimalisir kendala yang akan terjadi pada proses pelaksanaannya nanti. Kemudian pada saat pelaksanaannya, jika masih ada diantara guru ada yang terkendala masalah waktu dan tempat. Kepala sekolah dan guru yang bersangkutan berkomunikasi secara langsung membahas itu.

Selanjutnya Kepala SDN 10 Serindang memfungsikan perannya untuk mengontrol apakah program belajar tambahan sudah berjalan sesuai dengan perencanaan. Pengontrolan dilakukan oleh kepala sekolah dengan memantau langsung pelaksanaan pelajaran tambahan tersebut. Namun proses pemantauan itu dilakukan dalam suasana santai, tidak menyalahkan, dan penuh pengertian.

Bahkan menurut keterangan guru-guru, kepala sekolah juga ikut terlibat langsung dalam mengajar, secara lebih khusus mengajar pelajaran matematika untuk siswa kelas enam yang akan melaksanakan ujian sekolah. Hal ini juga dilatarbelakangi oleh kompetensi kepala sekolah yang dipercaya untuk memberikan pelatihan khusus kepada siswa-siswa yang berprestasi di tingkat kecamatan juga kemampuannya dalam bidang matematika yang diberikan kepercayaan oleh dinas pendidikan kabupaten Sambas untuk menjadi tim pembuat soal ujian mata pelajaran matematika di provinsi Kalimantan Barat.

Keterlibatan langsung kepala sekolah dalam mensukseskan tujuan sekolah yang memiliki prestasi akademik unggul ini pula membawa dampak pada sikap kepala sekolah yang memiliki empati yang tinggi kepada guru dalam melaksanakan tugas mengajarnya.

Hubungan kekeluargaan yang dibangun oleh kepala sekolah dan guru di SDN 10 Serindang ini pula didukung dengan status kepala sekolah yang merupakan warga Serindang yang beberapa diantara mereka lahir dan membesar di Desa Serindang. Kondisi saling mengenal lebih dekat ini menimbulkan rasa nyaman dan mengurangi rasa canggung sehingga guru lebih mudah untuk berkomunikasi baik itu menyampaikan ide, saran, kritikan bahkan keluhan.

Karakter kepala sekolah juga yang dikenal guru sebagai seseorang yang bersemangat, peduli, dan humoris memberikan mereka rasa nyaman tanpa ada tekanan dalam menyampaikan sesuatu. Serta kepala sekolah juga yang piawai memainkan peran dengan karakter guru yang berbeda. 
Hal ini juga didukung dengan waktu yang lama mereka mengenal satu sama lain.

Menurut Gibson, dkk (2014, p. 231) seorang pemimpin yang tidak melibatkan komunikasi akan menghadapi kesulitan yang tinggi. Kemudian penggunaan komunikasi interpersonal di SDN 10 Serindang ini merupakan cara yang paling tepat digunakan oleh seorang pemimpin di sekolah ini.

Keunggulan komunikasi interpersonal ini pula menurut Liliweri (2015, p.463) ialah bisa membangun relasi dengan orang lain. Keuntungan pertama dari komunikasi interpersonal ialah memperoleh kepuasan lahir dan batin. Kemudian komunikasi interpersonal yang efektif juga bisa mengurangi tingkat stres. Dengan adanya tempat berbagi pengalaman guru, berbagi suka dan duka, dan berbagi kelebihan serta kekurangan akan membuat guru lebih maksimal dalam menggali potensi dirinya dalam melaksanakan tugas mengajar.

Sedangkan Flyod (2011, p.22-23) mengatakan bahwa interpersonal communication occurs between two people (komunikasi interpersonal terjadi antara dua orang), interpersonal communication occurs within a relationships (komunikasi interpersonal terjadi dalam hubungan), interpersonal communication evolves within relationships (Komunikasi interpersonal berkembang dalam hubungan), interpersonal communication negotiates and defines relationships (komunikasi interpersonal bernegosiasi dan mendefenisikan hubungan).

Dengan demikian maka komunikasi interpersonal yang digunakan oleh Kepala SDN 10 Serindang sebagai sarana kepemimpinannya tepat dengan melaksanakan komunikasi interpersonal sebagai berikut: 1) terjadi secara langsung antara pribadi kepala sekolah dan guru, 2) ada hubungan timbal balik antara kepala sekolah dan guru, 3) ada proses transaksi interpersonal yaitu hubungan dekat (personal) antara kepala sekolah dan guru 4) hubungan antara kepala sekolah dan guru terjadi dalam waktu yang lama dan kontinum (berkelanjutan).
Kemudian, di antara hambatan yang dialami diantaranya adalah pemilihan waktu untuk berkomunikasi secara interpersonal. Hal ini dikarenakan tugas guru yang padat yang biasanya hanya bertemu pada saat jam istirahat sekolah. Kemudian, berdasarkan jawaban guru di SDN 10 Serindang, kesibukan kepala sekolah di awal tahun pelajaran dan akhir tahun juga menjadi penghambat untuk menyampaikan permasalahan guru dalam melaksanakan tugasnya. Mereka mengatakan bahwa untuk menyampaikan sesuatu harus melihat situasi dan kondisi terlebih dahulu.

Gibson (2006,

p.249-256)

mengatakan bahwa hambatan waktu memberikan hambatan penting dalam komunikasi. Hal ini disebabkan oleh seorang pemimpin tidak memiliki waktu lebih banyak kepada bawahannya. Sebagaimana juga diungkapkan Supartha dan Sintaasih (2017, p.86-87) bahwa tekanan waktu menjadi hambatan untuk mendapatkan komunikasi interpersonal yang efektif.

Hambatan komunikasi interpersonal lain yang dialami kepala sekolah dan guru SDN 10 Serindang ialah ketika melalui media sosial. Berdasarkan wawancara kepada kepala sekolah dan guru, mereka memiliki jawaban yang serupa yakni apabila informasi yang harus disampaikan melalui media whats app atau telepon seringkali pesan itu direspon lambat oleh kedua belah pihak, baik itu pada kepala sekolahnya maupun dibagian gurunya. Hal ini biasa disebabkan oleh kualitas jaringan yang buruk serta posisi perangkat telpon yang tidak selalu berada di dekat pemilik telpon tersebut baik kepala sekolah maupun guru. Hal ini di jelaskan oleh Liliweri (2015, p.459-460) bahwa hambatan komunikasi interpersonal disebabkan oleh media yang tidak mendukung untuk menyampaikan pesan.

Fisik juga menjadi penghambat dalam berkomunikasi. Terutama bagi guru baru yang berbeda jenis kelamin. Guru perempuan, terutama guru yang lebih muda merasa segan dan malu menyampaikan 
permasalahannya. Hal ini berbeda dengan guru laki-laki yang lebih mudah dan santai untuk menyampaikan sesuatu. Hal ini dibenarkan ketika wawancara dengan kepala sekolah dan beberapa guru yang bersangkutan. Berdasarkan pendapat Liliweri (2015, p. 460-461) bahwa hambatan fisik memberikan dampak dalam pelaksanaan komunikasi interpersonal yang baik.

Selain hambatan-hambatan di atas, hambatan lainnya ialah hambatan psikologis. Selain beda perlakuan dalam berkomunikasi antara guru laki-laki dan guru perempuan. Usia juga menjadi faktor penghambat komunikasi. Perasaan tersinggung yang dirasakan oleh guru, maupun kondisi emosional yang sedang buruk membuat komunikasi interpersonal tidak berlangsung baik. Perbedaan status dianggap ancaman oleh mereka yang lebih rendah jabatannya (Gibson, p.249-256).

Selanjutnya, upaya yang telah dilakukan oleh kepala sekolah dalam mengatasi hambatan komunikasi interpersonal ialah dengan membangun rasa empati terhadap tugas guru. Sebagai bentuk empati, kepala sekolah berusaha memahami dan men-support guru dalam melaksanakan tugasnya. Serta bersama-sama meningkatkan kompetensinya sebagai pendidik. Sebagaimana di ungkapkan oleh DeVito (1967) dalam Thoha (2014, p.98) bahwa empati merupakan satu di antara cara untuk mencapai komunikasi interpersonal yang efektif. Hal ini senada dengan pendapat Gibson, dkk (2006, p.257-261) bahwa empati adalah cara untuk meningkatkan kualitas komunikasi interpersonal.

Kepala sekolah dengan jabatannya sebagai pengambil keputusan di sekolah berusaha memenuhi sarana guru dalam belajar. Di antaranya dengan memenuhi kebutuhan laptop untuk masing-masing guru, menyediakan infocus untuk metode pengajaran baru, pemasangan wifi agar guru bisa menambah pengetahuan dan referensi mengajar dari internet. Serta menyediakan ruangan yang nyaman bagi guru. Berdasarkan hasil observasi, peneliti melihat ruangan guru yang bersih dan rapi. Ruangan guru merupakan tiga bagian dalam satu bangunan. Ruang guru, ruang tamu, dan ruang kepala sekolah.

Di antara kebiasaan yang dilakukan oleh Kepala SDN 10 Serindang ialah kebiasaan untuk mendengar. Kepala sekolah mendengarkan cerita-cerita guru dalam perjalanannya melaksanakan tugas pendidikan. Hal ini biasanya berlangsung pada saat jam istirahat, kepala sekolah yang juga berbaur disatu ruangan dengan posisi kursi duduk melingkar memudahkan untuk berkomunikasi satu dengan yang lain. Pada situasi tersebut, secara tidak langsung, guruguru menyampaikan permasalahannya dengan berbagi kepada kepala sekolah dan teman guru yang lain. Hal ini sejalan dengan pendapat Gibson, dkk (2006, p.257-261) dan Supartha dan Sintaasih (2017, p.87) bahwa mendengarkan secara efektif merupakan cara untuk meningkatkan kualitas komunikasi interpersonal.

Upaya lain yang dilakukan oleh kepala sekolah ialah dengan cara kepala sekolah mengulangi informasi baik itu secara langsung pada saat kumpul jam istirahat maupun secara personal di ruangan kepala sekolah dengan menggunakan bahasa yang lebih sederhana. Guru SDN 10 Serindang mengatakan bahwa sering dibimbing langsung oleh kepala sekolah jika ada kendala yang dihadapi pada saat melaksanakan proses belajar mengajar. Hal ini diperkuat dengan pendapat Gibson, dkk (2006, p.257-261) dan Supartha dan Sintaasih (2017, p.87) bahwa pengulangan dapat menjadi solusi untuk mencapai komunkasi interpersonal yang efektif dan berkualitas. Kemudian Spitzberg \& Cupach (1989) dan Wilson \& Sabee (2003) dalam DeVito (2013, p.10) mengatakan bahwa "your ability to communicate effectively (as source and reciever) is your interpersonal competence". Kemampuan aada untuk berkomunikasi secara efektif, baik itu sebagai sumber maupun penerima, adalah kompetensi interpersonal anda.

Kepala SDN 10 Serindang selalu mempertimbangkan kesiapan psikologi dan 
kondisi kesehatan guru. Kesiapan yang dimaksudkan ialah kepala sekolah akan berkomunikasi dengan guru saat mereka tidak dalam keadaan sibuk atau sedang dalam kondisi santai dalam arti yang lain dilaksanakan pada waktu yang tepat. Umam (2012, p.168) mengatakan bahwa ketepatan baik itu bahasa atau kebenaran informasi harus betul-betul diperhatikan. Hal ini dilakukan agar komunikasi yang dilakukan tepat apakah harus menggunakan bahasa verbal maupun nonverbal. Komunikasi non verbal menurut Ting-Toomey (1999) dalam Hill, dkk (2007, h.121) akan "signify who we are via our artefacts (e.g. the clothes we wear), our vocal cues, our nonverbal selfpresentation modes, and the interpersonal spaces we claim for ourselves. Pesan nonverbal ini menandakan siapa kita melalui fisik kita (misal pakaian yang digunakan), isyarat vokal, jenis presentasi diri nonverbal, serta ruang interpersonal yang kita akui sebagai diri kita sendiri.

\section{SIMPULAN DAN SARAN Simpulan}

Berdasarkan penelitian yang telah dilaksanakan, dapat disimpulkan dalam berkomunikasi secara interpersonal terhadap guru dalam meningkatkan prestasi akademik di SDN 10 Serindang, kepala sekolah melaksanakan komunikasi interpersonal sebagai berikut: (a) terjadi secara langsung antara kepala sekolah dan guru ketika membahas program pelajaran tambahan, (b) ada hubungan timbal balik dalam berkomunikasi antara kepala sekolah dan guru, (c) pesan yang disampaikan kepala sekolah bersifat pribadi baik secara verbal maupun nonverbal (d) hubungan antara kepala sekolah dan guru terjadi dalam waktu yang lama dan kontinum (berkelanjutan). Hambatan Komunikasi interpersonal dilalui oleh Kepala SDN 10 Serindang yaitu (a) hambatan waktu yaitu waktu kepala sekolah untuk berkomunikasi kepada guru sangat singkat terutama ketika awal tahun ajaran baru serta akhir tahun, (b) pengaruh media sosial juga menjadi hambatan komunikasi karena kualitas sinyal yang buruk juga pemilik perangkat media yang tidak selalu berada di dekat media tersebut, (c) pengaruh fisik juga menjadi penghambat komunikasi interpersonal di mana perlakuan yang berbeda diberikan kepada guru laki-laki dan guru perempuan, serta (d) pengaruh psikologis juga turut menjadi penghambat komunikasi interpersonal di SDN 10 Serindang, faktor usia juga menjadi penunjang rasa ketersinggungan sehingga tujuan komunikasi tidak dapat dicapai dengan baik.

Cara mengatasi hambatan komunikasi interpersonal kepala sekolah dalam meningkatkan prestasi akademik SDN 10 Serindang adalah dengan (a) kepala sekolah membangun sikap empati yang tinggi terhadap tugas guru, (b) kepala sekolah juga membiasakan diri menjadi pendengar yang baik agar pesan yang ingin disampaikan guru dapat diterima dengan baik, (c) mengulangi informasi yang kurang jelas juga dilakukan oleh Kepala SDN 10 Serindang dalam kondisi yang santai pada saat jam istirahat, kemudian (d) menentukan waktu yang efektif merupakan cara yang dilakukan oleh kepala sekolah dalam mengatasi hambatan komunikasi interpersonal.

\section{Saran}

Pola komunikasi interpersonal yang dilakukan Kepala SDN 10 Serindang dalam meningkatkan prestasi akademik di SDN 10 Serindang sebaiknya tetap dilaksanakan dan dikembangkan. Hambatan yang terdapat di SDN 10 Serindang dapat dijadikan sebagai sarana evaluasi dikemudian hari bagi kepala SDN 10 Serindang sehingga memberikan pengaruh baik pada efektivitas kegiatan belajar mengajar yang akan berdampak pada prestasi 
akademik yang akan diraih sekolah tersebut.

Cara mengatasi hambatan komunikasi dalam meningkatkan prestasi akademik di SDN 10 Serindang yang telah dilaksanakan oleh kepala sekolah bisa dilanjutkan dan dilakukan lebih baik lagi untuk meningkatkan prestasi akademik di sekolah tersebut di masa yang akan datang. Menentukan waktu rutin untuk evaluasi secara pribadi terhadap masing-masing guru juga bisa dijadikan satu diantara upaya untuk mengatasi hambatan yang telah dilalui sebelumnya.

\section{DAFTAR RUJUKAN}

DeVito, J.A. (2013). The Interpersonal Communication Book. Thirteenth Edition. USA: Pearson Education.

Flyod, K. (2011). Interpersonal Communication. New York: McGraw Hill.

Gibson, J.L., John M.I, James H.D, Jr, R.K. (2006). Organizations, Behavior, Sructure and Proceses. Boston: McGraw-Hill.

Hartley, P. (1999). Interpersonal Communication, Second Edition. London: Roudledge.
Hill, A., Watson. J, Rivers. D., \& Joyce. M. (2007). Key Themes in Interpersonal Communication. England: McGrawHill Education.

Liliweri, A. (2015). Komunikasi Antarpersonal. Jakarta: Kencana.

Rosyid, Z.R., Mustajab, \& Abdullah, A.R. (2019). Prestasi Belajar. Batu: Literasi Nusantara.

Rusman. (2017). Belajar dan Pembelajaran: Beorientasi Standar Proses Pendidikan. Jakarta: Kencana.

Supartha, W.G., \& Sintaasih, D.K. (2017). Pengantar Perilaku Organisasi: Teori, Kasus, dan Aplikasi Penelitian. Denpasar Timur: Setia Bakti.

Thahir, A. (2014). Belajar. Bandung: Media Sains Indonesia.

Thoha, M. (2014). Perilaku Organisasi: Konsep Dasar dan Aplikasinya. Jakarta: Rajawali Pers.

Umam, K. (2012). Manajemen Organisasi. Cet. 1. Bandung: Pustaka Setia.

Wahyudi. (2012). Kepemimpinan Kepala Sekolah dalam Organisasi Pembelajar (Learning Organization). Cet. 3. Bandung: Alfabeta. 